\title{
Spindt 型電子源の現状と展望*
}

\author{
伊藤 茂生 ${ }^{* 1} \cdot$ 田中 満*1 . 小原 有司*1
}

\section{Current Status of the Spindt-type Field Emitter}

\author{
Shigeo $\mathrm{ITOH}^{* 1}$, Mitsuru TANAKA*1 and Yuji OBARA*1 \\ *1Product Development Center, Futaba Corporation. 1080 Yabutsuka, Chosei-mura, Chosei-gun, Chiba-ken, 299-4395
}

(Received March 14, 2005, Accepted July 2, 2005)

\section{1. はじめに}

電子放出機構としては, 熱電子放出, 電界効果電子（電界 放出) (Field Emission), 光電子放出, 二次電子放出などが あるが，この中の電界放出電子を用いて電子線励起発光を行 わせたディスプレイである Field Emission Display (FED) が，この十年来期待のフラットパネルディスプレイとして話 題に上っている. FED は, 自発光, 高コントラスト, 高速 応答, 映像表現に重要な階調性に優れるなど, CRTの画質 を受け継ぐとともに，CRT と異なり大画面化しても周辺部 まで画像歪なく良好なフォ一カスを保ち, 映像芸術の作品鑑 賞を可能とさせるポテンシャルを持つフラットパネルディス プレイとして注目されている.

半導体微細加工技術の進歩により, 電極間距離が $\mu \mathrm{m} レ ヘ ゙$ ル, 先端が数十 $\mathrm{nm}$ 以下の曲率半径を持つ多数の電界放出工 ミッタを, Si ウエハまたはガラス基板上に, 再現性良く形 成することが可能となり, 数 $10 \mathrm{~V}$ の電圧印加で真空中, 室 温において電界放出が行えるようになった。このエミッタを 形成したカソード基板と, 蛍光面を形成したアノード基板と を, 真空気密容器中に対向させて, 電子線励起発光させる表 示素子が FEDである.

マイクロ電界放出素子としては, Spindt 型が良く知られ ている. Spindt 型エミッタは1970年代前半 SRI International (米)のC. A. Spindt 氏により発明されたもので1), 各コー ン直下に抵抗を持たせる構造などの提案 2 をを行い, 当初は高 周波素子用の電子源として検討された，その後, LETI（仏） の R. Meyer 氏などにより，初めてガラス基板上のディスプ レイ用電子源へ応用され3), エミッタの安定化や発光部の均 一性改善に有効な, 薄膜抵抗層を用いた電流安定化構造が提 案された ${ }^{4)}$. その後 10 年以上にわたり, 多くの研究機関や企 業が FEDの開発に携わってきた。しかしその開発は, 必ず しも順調に進んできたわけではなかった。

本質的に FED は真空管であり, エミッタの微細加工と同 様に, 真空技術が大变重要な役割をもつ. 例えば, マイクロ メーターレベルの組み立て精度, 薄板ガラスの真空パッケー ジ，小さな空間しか持たないフラットパネル内で安定な電界 放出を維持する真空技術, パネル内部の真空条件を維持する ために適した材料の選択, FED 画像への悪影響が少ない支

* 平成17年 2 月 7 日 日本真空協会 2 月研究例会で発表

*1 双葉電子工業(物) 商品開発センター（T299-4395 千葉県長生 郡長生村薮塚1080)
柱構造の開発, 不要なエミッションノイズや放電対策などが 必要となる.これらの課題は, 半導体微細加工技術を用いた だけでは解決が困難であった.

当社では, 1989年から Spindt 型Mo エミッタを FED 用 電子源として検討してきた. 現在 Mo 金属を用いた Spindt 型エミッタの開発段階は終了しつつある. 低電圧モノカラー FED は, 高精細グラフィック蛍光表示管（VFD）の置き換 えとして製品化された。当社ではその製品において, FED の信頼性, 輝度の均一性や FED が十分実用に耐える定電圧 駆動 1 万時間以上の寿命をもつことを初めて実証した. 更 にこれまでの低電圧 FED 技術をべースに, フルカラー FEDの開発に取り組み, 現在量産準備の段階である.

また1995年より NHK 放送技術研究所とSpindt 型エミッ タをディスプレイ以外の用途に用いることにより，これまで 実現し得なかった, 新しい撮像素子を創生する試みも行って いる5).

いずれも Spindt 型エミッタが電子源として使用され，こ れまで従来の熱電子源では実現出来なかった課題が解決され ると共に, 冷陰極電子デバイスの応用が現実のものになりつ つある。ここでは，現在最も完成度の高いSpindt 型エミッ タの当社での現状とその応用について述べる.

\section{Spindt 型エミッタについて}

Spindt 型エミッタの構造を図 1 に示す。 また, 図 2 に, Spindt 型エミッタの断面 SEM 写真を示す6).

Spindt 型電界放出素子は, SRI International の C. A. Spindt 等が蒸着エミッタとして開発したのが最初であり, そのユニークな製作法などから Spindt 型エミッタと呼ばれ ている1).その作製方法は巧みに真空蒸着法の特徵を生かし たもので, その作製手順を図 3 に示す. Si 基板の場合, 表

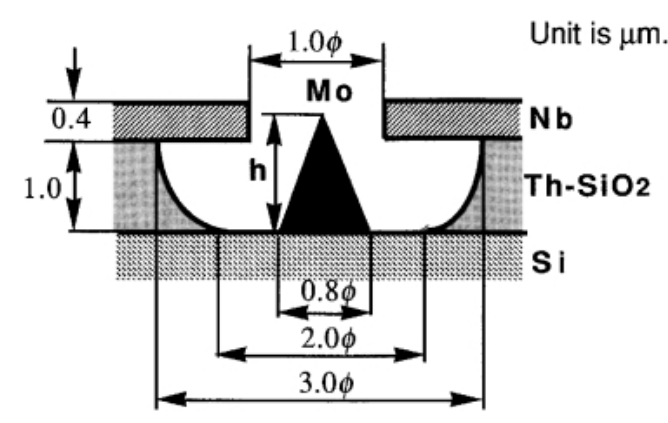

図 1 Spindt 型エミッタの基本構造 


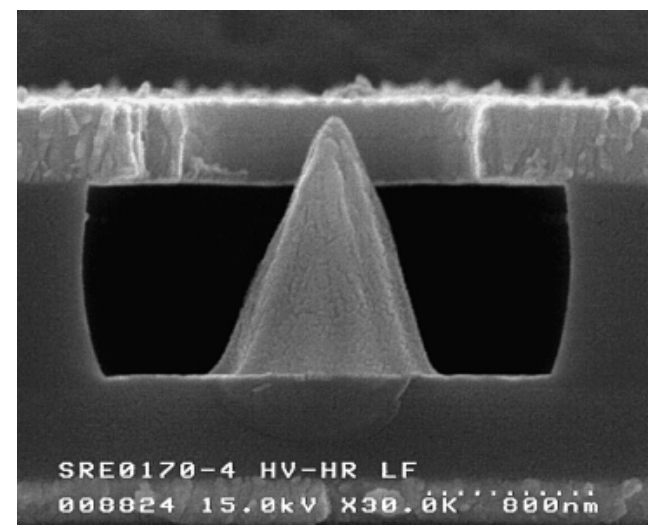

図 2 Spindt 型エミッタの断面 SEM 写真

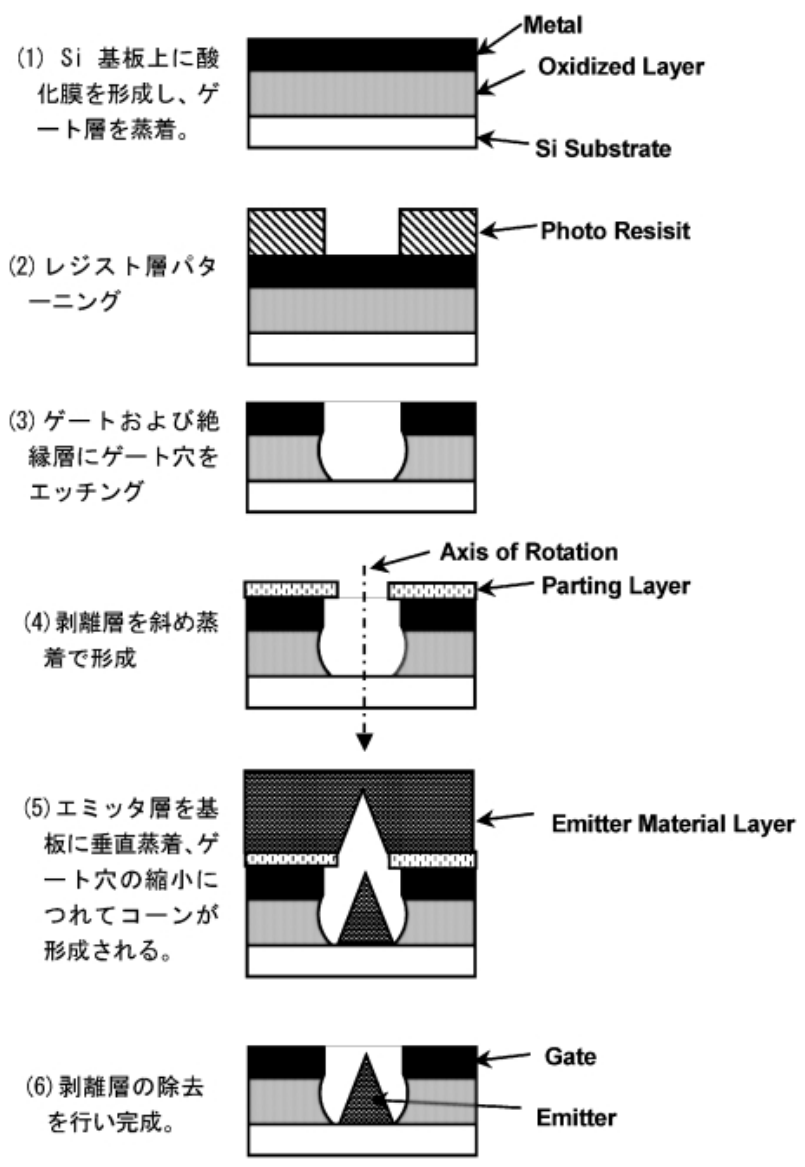

図 3 Spindt 型エミッタの作製工程

面に膜厚約 $1 \mu \mathrm{m} の \mathrm{SiO}_{2}$ 熱酸化膜を形成し，その上に $\mathrm{Mo}$, $\mathrm{Nb}$ 膜などのゲート層を形成する。その後ゲート穴をパター ニングし，斜蒸着で $\mathrm{Al}$ などの剥離層を形成する。ここで剥 離膜の形成に斜め蒸着を用いるのは，剥離膜材料がゲート穴 内へ付着するのを, 極力避けるためである. その後 Mo など のエミッタ材料を基板に対して垂直方向から蒸着する.ゲー 卜上の堆積膜が厚くなるに伴い, 開口径が縮まり, ゲート穴 底部に蒸着されたエミッタ堆積膜の径が縮まりながら円錐台 形状が形成され，完全にゲート穴径が塞がった時，ゲート穴 内部にエミッタ材料の円錐コーンが形成される.最後に剥離 層をゲート上の堆積層と一緒に剥離除去して完了となる.ガ
ラス基板の場合は, カソード電極層なぞを形成した後, スパ ッタリング蒸着法や CVD 法により絶縁層を形成した後は $\mathrm{Si}$ 基板の場合と同じプロセスである.

Spindt 型エミッタは以下のような特長をもっている.

(1) 理想的な電界集中構造を持ち, 分配率（アノード電流/ カソード電流）は $98 \%$ 以上.

(2) エミッタの配置などによりエミッション領域の設計が可 能.

(3) 電子ビームの広がりが小さい（約 30 度).

(4) ガラス基板が使え大型化に有利.

(5) 薄膜プロセスが主であるため，放出ガスが少ない.

(6) カソード材料・構造による低電圧化が可能.

一方ディスプレイ用電子源としては，そのエミッションポ イント毎の放出の均一性が重要であり, カーボンナノチュー ブやDLC などを使用する場合でも, 微細加工や薄膜プロセ スを多用することを前提にした構造では, カソード基板のコ スト面では, 大きなメリットは見出されなくなる. 現時点で は, Spindt 型エミッタは, 依然として特性的に最も安定で 実用的な電子源である.

その一方, Spindt型の場合, カスタム化した製造設備を 必要とし，生産に対する取り組みが現在行われている7).

\section{Spindt 型エミッ夕使用 FED}

\subsection{FED の特長}

FED は他のディスプレイでは実現できない優れた特長を いくつか持つ. 例えば, パネル厚さは約数 $\mathrm{mm}$ であり, 自 発光で，そのサイズに関係無く原理上画面丕みを生じず，上 下左右約 170 度以上の広視野角を持ち, 電子源は能動素子な しに, 直接アナログやデジタル信号で $\mu \mathrm{s}$ 台の高速応答を行 い，受信管と同様に耐環境性に優れ，周囲環境の磁気や地磁 気の影響を受けず，熱電子源と異なり，発熱が無く，瞬時点 灯が可能, 表示部以外のデッドスペースが小さい. またエミ ッション電流が輝度に対応し, 電力は主に発光部で消費され るため, 低消費電力ディスプレイとして期待されている8). FED はこのような多くの特長を持っているが，なんと言っ ても最大の特徴は, FED が真空デバイスであることである. FED の基本的な機能は, 原理的に CRT や VFD と同じであ り, そのため, 厳しい環境条件下で安定に機能を発揮するこ とができる。

\subsection{FED の構造}

Spindt 型エミッタ使用フルカラー FED パネルの基本構造 を図 4 に示す. カソード基板とアノード基板ガラス厚はそれ ぞれ $1.1 \mathrm{~mm}$, 支柱長は $0.6 \mathrm{~mm}$ であるため, 総パネル厚は $2.8 \mathrm{~mm}$ になる. カソードとしては, ゲート電極と集束電極 は $\mathrm{Nb}$, エミッタは Mo, 支柱材料としてはガラスファイ バーが用いられている. カソード基板において, ゲート電極 とカソード電極の交差部に Spindt 型エミッタが形成され, $\mathrm{X}-\mathrm{Y}$ マトリックス選択駆動が行われる. カソードは漏れ発 光を防止するため, ゲート電極の上に，集束電極を持つ.

図 5 にカソード基板の SEM 写真を示す.ゲートーカソー ド電圧は $40 \mathrm{~V} \sim 65 \mathrm{~V}$ で駆動している. 図 6 にカソードの断 面概念図を示す 9 . 


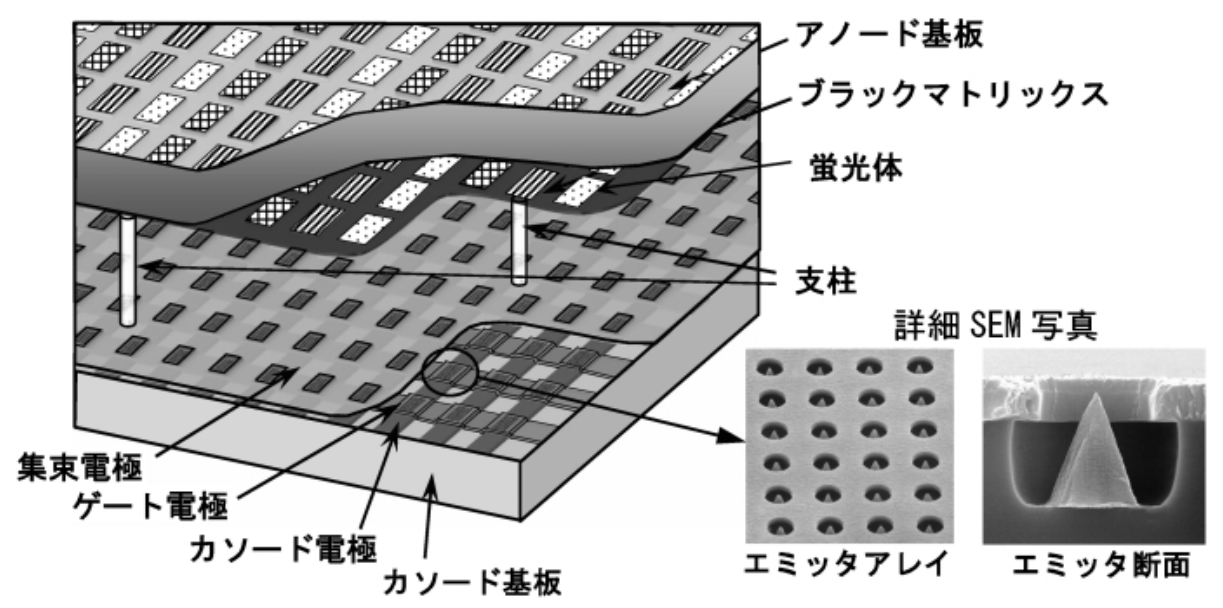

図 4 Spindt 型エミッタ使用カラー FED パネルの基本構造

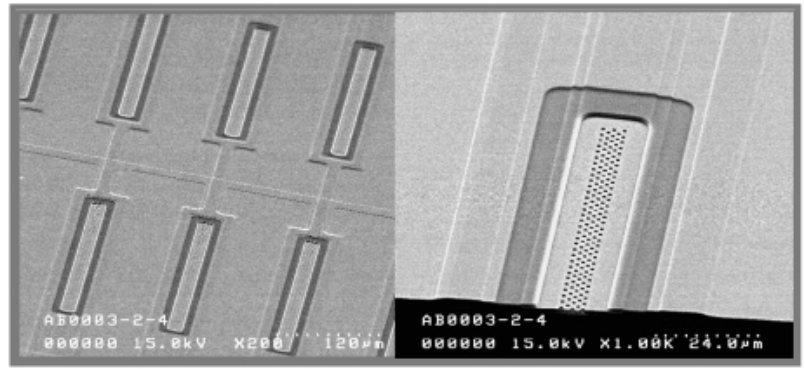

図 5 エミッタアレイの SEM 写真

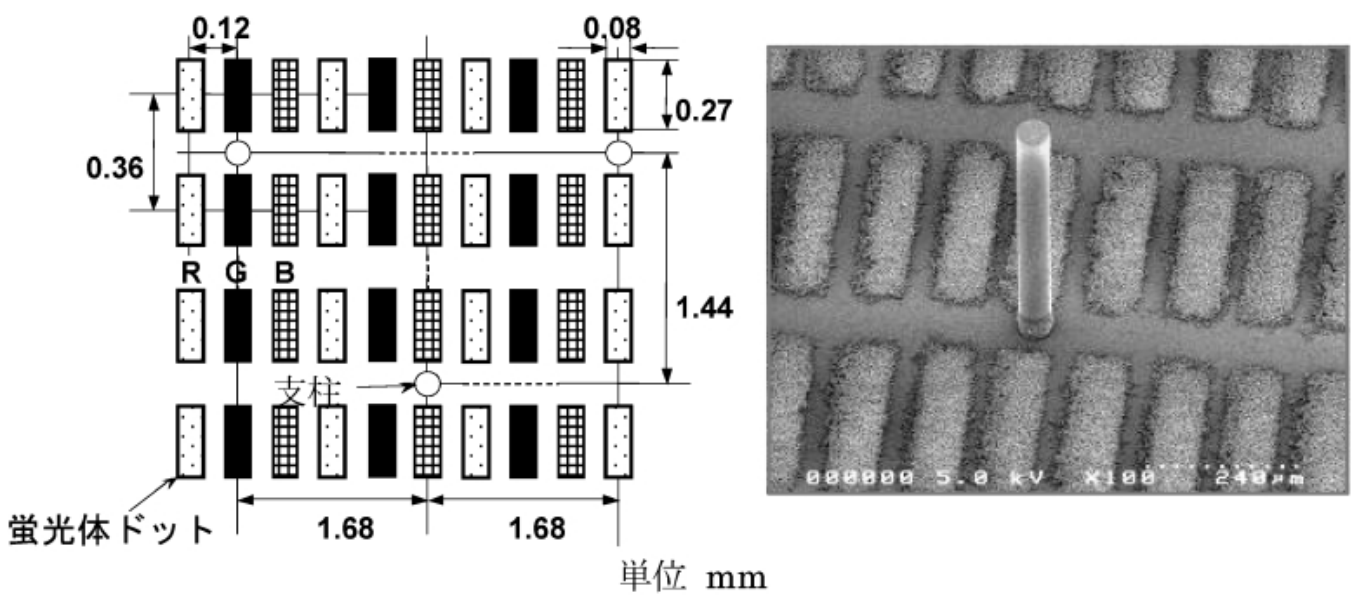

図 7 アノード基板の蛍光体ドットのレイアウトおよびその SEM 写真
アノード基板は, 蛍光体被着部を空状に開口した $\mathrm{Al}$ ア ノード電極, カラー蛍光体抢よび支柱から形成されている. アノード電極は, その各開口部に各カラー蛍光体の画素が形 成され，開口部を通してアノード基板外側から，発光部が観 察される. 蛍光体下部の $\mathrm{Al}$ アノード電極は, 漏れ発光を抑 える「ブラックマトリックス」として機能する.アノード電 圧は現在 $3 \mathrm{kV}$ 以下であるため, 本 FED はメタルバック層 は持たず，シンプルなアノード構造を実現している.

我々は低電圧モノカラー FED 以来, 独特の形成法を用い た支柱構造をとっているため, 蛍光面に載置しても観察面側

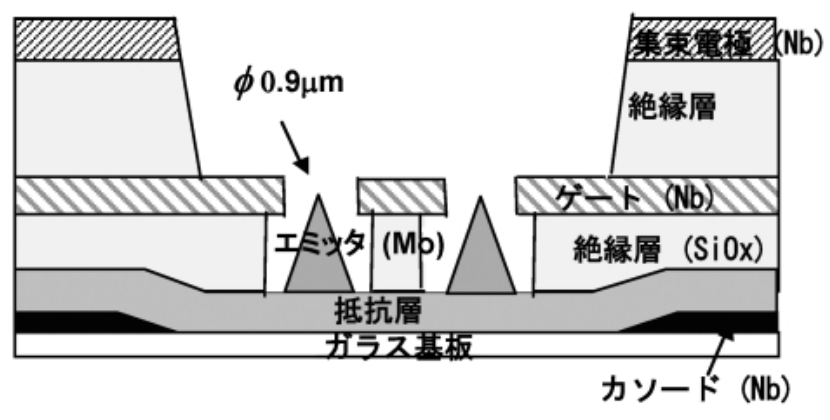

図 6 カソードの断面概念図 


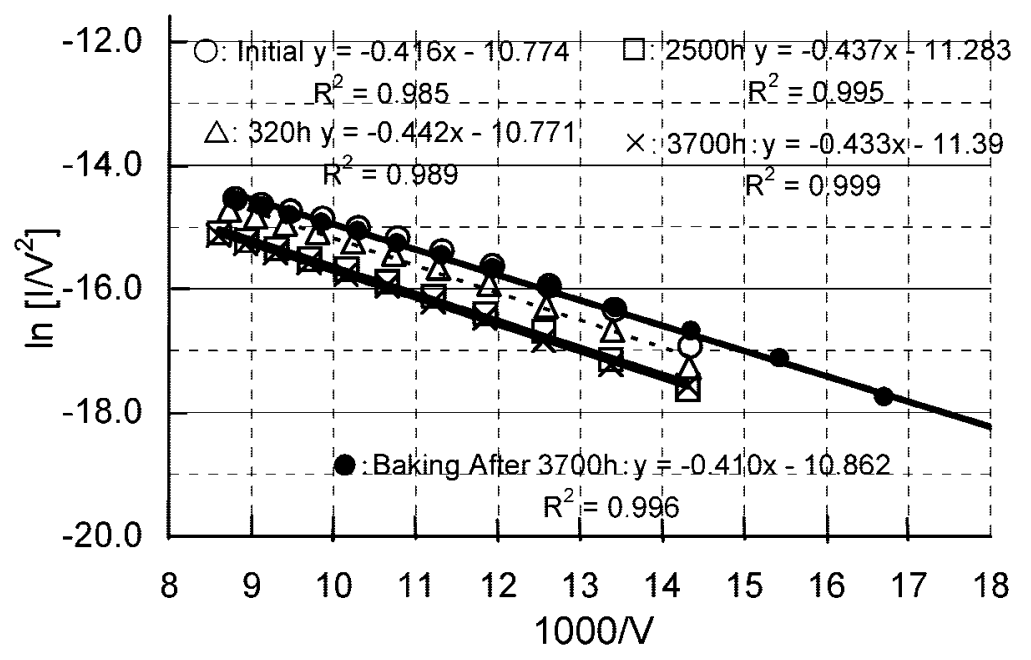

図 8 モノカラー FED パネルの定電圧駆動時間による F-N プロットの変遷

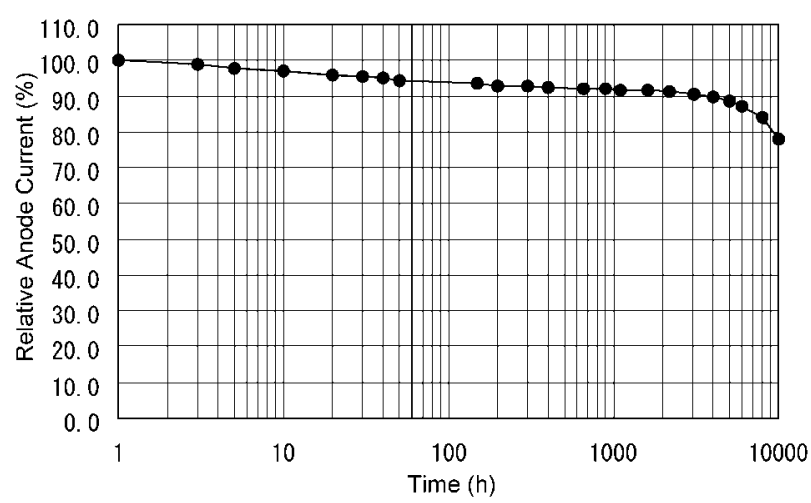

図 9 モノカラーFED パネルのエミッション寿命特性例

Nordheim プロットの定電圧駆動時間による変遷抢よび 3,700 時間定電圧駆動テスト劣化後のパネルの $200^{\circ} \mathrm{C}-2 \mathrm{~h}$ 加 熱処理後のプロットを示す.

図 8 よりエミッション特性が駆動時間に応じて劣化し， それが $200{ }^{\circ} \mathrm{C}-2 \mathrm{~h}$ 加熱処理により寿命試験の初期状態に回復 出来ることを示している6 ${ }^{6,12)}$.この回復現象はカラーFED に扔いても生じることが確認された．この結果は, 少なくと もアノード電圧 $3 \mathrm{kV}$ 以下では, エミッション劣化がエミッ タのイオンダメージなどによる構造的破壊などではなく, 単 なるガス吸着による劣化であることを示している.

我々はモノカラーFEDの開発初期において, FEDの内 部構成材料やプロセスを検討することにより, 定電圧駆動で 輝度の初期值からの半減が 1 万時間以上を保証しうるモノ カラーFED をプロ用映像製品のモニターとして供給できる に至った。 モノカラーFED のエミッション寿命特性の 1 例 を図 9 に示す。このことから FED の優れた信頼性や特性が 実証されたと考えている.

FED の寿命特性の第 2 の要因は, 蛍光体の発光効率の劣 化である. $\mathrm{Y}_{2} \mathrm{SiO}_{5}$ : Tbの場合, 積算電荷量から計算する と, 蛍光体の寿命は実使用において 6,000 時間以上となる。

\section{4 フルカラー FED の特性}

当社のSpindt 型エミッタを用いた各種フルカラー FED の特性を表 1 に示す ${ }^{13)}$.

\section{4. 冷陰極 HARP 撮像板}

1995年より, NHK 放送技術研究所と, 次世代の超高感 度・小型撮像デバイスをめざして, 新しいタイプの撮像デバ イス「冷陰極 HARP 撮像板 (Field Emitter Array Image Sensor with a HARP Target, 以下 FEIS と略す)」の開発に 取り組んでいる. FEISは, 光を電荷に変換し増幅する HARP 膜と, その電荷を読み出すための電子ビームを放出 する冷陰極アレイとを組反合わせたものである. 入射光量に 応じて HARP (High-gain Avalanche Rushing amorphous Photoconductor) 膜上に形成された電荷 (正孔) パターンを, 冷陰極アレイから放出した電子ビームで順次読反出すこと で, 映像信号を得ることができる.その概念図を図10に示 す. 今回, 画素面積を $50 \mu \mathrm{m} \times 50 \mu \mathrm{m}$ にした $25.4 \mathrm{~mm}$ （1イ ンチ), $256 \times 192$ 画素撮像板と, 新たに永久磁石を用いた電 子ビーム集束系を開発し，画質の飛躍的改善が確認された。 各画素に対応するエミッタアレイから, $4 \mu \mathrm{A} /$ アレイ以上の 電子ビームが射出され, HARP 膜内面上をラスタースキャ ンする. HARP 膜厚は $4 \mu \mathrm{m}, \mathrm{HARP}$ 膜と FEA 間のギャッ プは約 $1.8 \mathrm{~mm}$ ，中間にあるメッシュ電極には $300 〜 350 \mathrm{~V}$ を 印加し, 集束用磁界は磁束密度約0.11テスラがかけられてい る14).メッシュ電極は電子ビームの引き出しと余㮃電子の 吸収を行う。従来の HARP管と FEIS の外観を図11に示 す．またこれまでの開発経過を図12に示す. FEIS の技術推 移に伴い, 撮像画質の改善が実現された.

FEIS に期待される特性としては, 小型化以外に超高感度 (CCD の100倍以上), 高精細, 低消費電力, 広ダイナミック レンジなどが挙げられる. 高感度化に扔いては, 感度を左右 する HARP 膜への印加電圧として, 固体素子と異なり高電 圧がかけられるという真空管の特長が生かされ, HARP 撮 像管の次世代デバイスとして開発を進めている.

今後更に FEIS の性能向上を目指しての開発が進められる が, その実現により, 超高感度の電子の眼として, 医療・安 全・科学技術などの分野で社会に貢献出来る機会は, 益々拡 がるものと思われる. 
表 1 Spindt 型エミッタを用いた各種フルカラー FED の特性

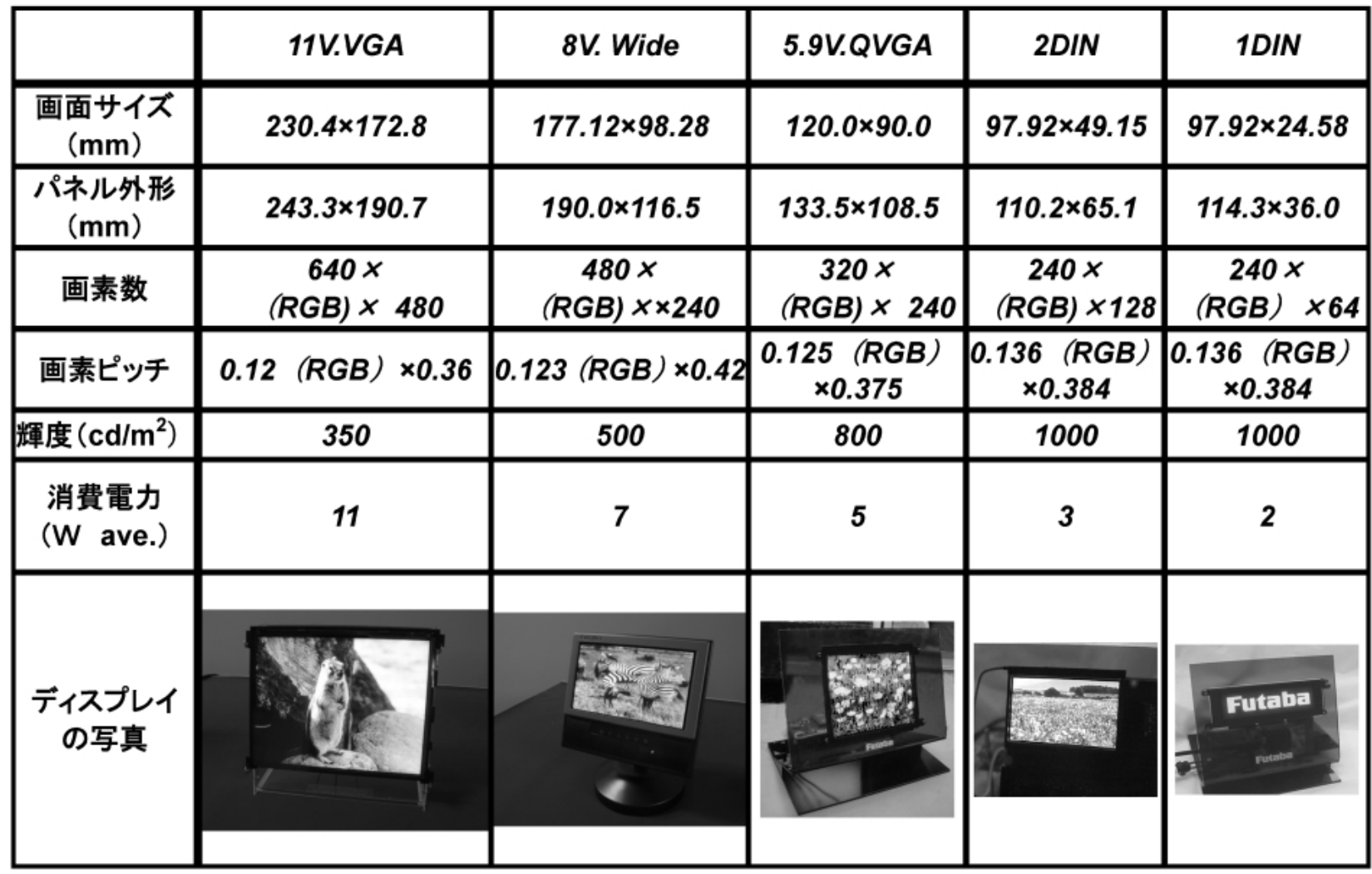

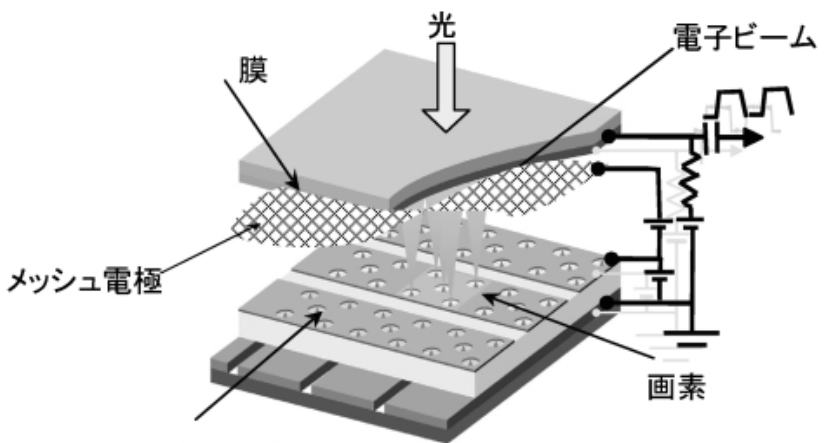

Spindt 型エミッタアレイ

図10 冷陰極 HARP 撮像板の概念図

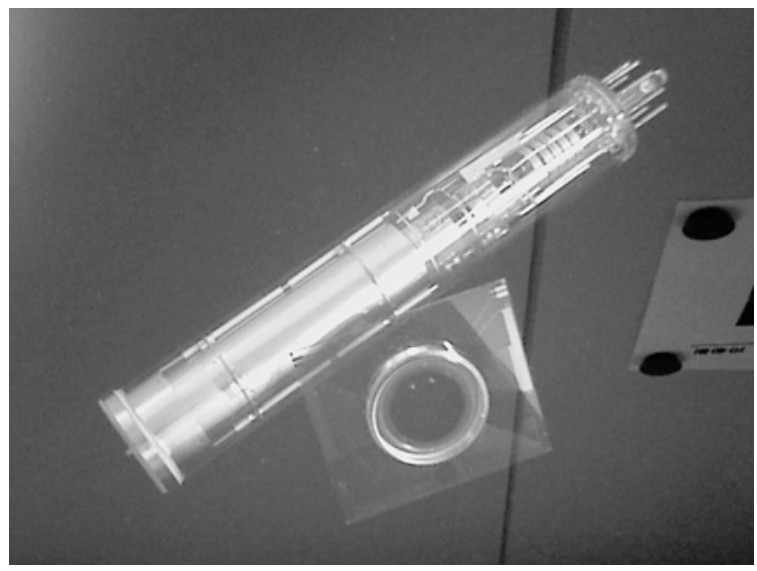

図11 従来の HARP管（左上）と FEIS（右下）

\section{5.おわりに}

Spindt 型モノカラーFED は既に製品化されて市場に供給 され，高い信頼性と優れた特性を持つことを証明した。フル カラーFED は量産準備に入っている．また FED は他のフ ラットパネルディスプレイでは実現できない低消費電力デバ イスとしても期待されている．FED は今後, 小型・中型サ イズのパネルだけではなく，大画面サイズのパネルとしても 開発が進み，21世紀の社会生活に相応しいフラットパネル ディスプレイデバイスの 1 つとして社会に寄与でき得る製 品になるものと思われる. また, 冷陰極撮像板のように, こ れまで熱電子源では実現できなかった新しい電子デバイスが 創生されようとしている.

真空技術は 17 世紀から社会に科学として取り入れられた 古い技術であるが，熱院極真空管を生み出し，それが CRT やマイクロ波管に展開する一方，その間発達した真空技術が 薄膜形成技術などを生み出した。 またそれがトランジスタな ぞの固体素子を生み出し, またその固体素子の製造過程で発 達した半導体微細加工技術が新たにフラットパネルディスプ レイやSpindt 型エミッタに代表される冷陰極素子を生み出 した．すべて真空技術を中心として螺旋展開しながら電子デ バイスが発展してきたかのように見える（図13）.今後も， 真空技術を基調として, Spindt 型電子源を用いた新たな電 子デバイスが生み出されると共に, その関連技術から生まれ た新技術もまた社会に貢献するという展開が続くものと思わ れる。

なお冷陰極撮像板の開発については NHK 放送技術研究所 


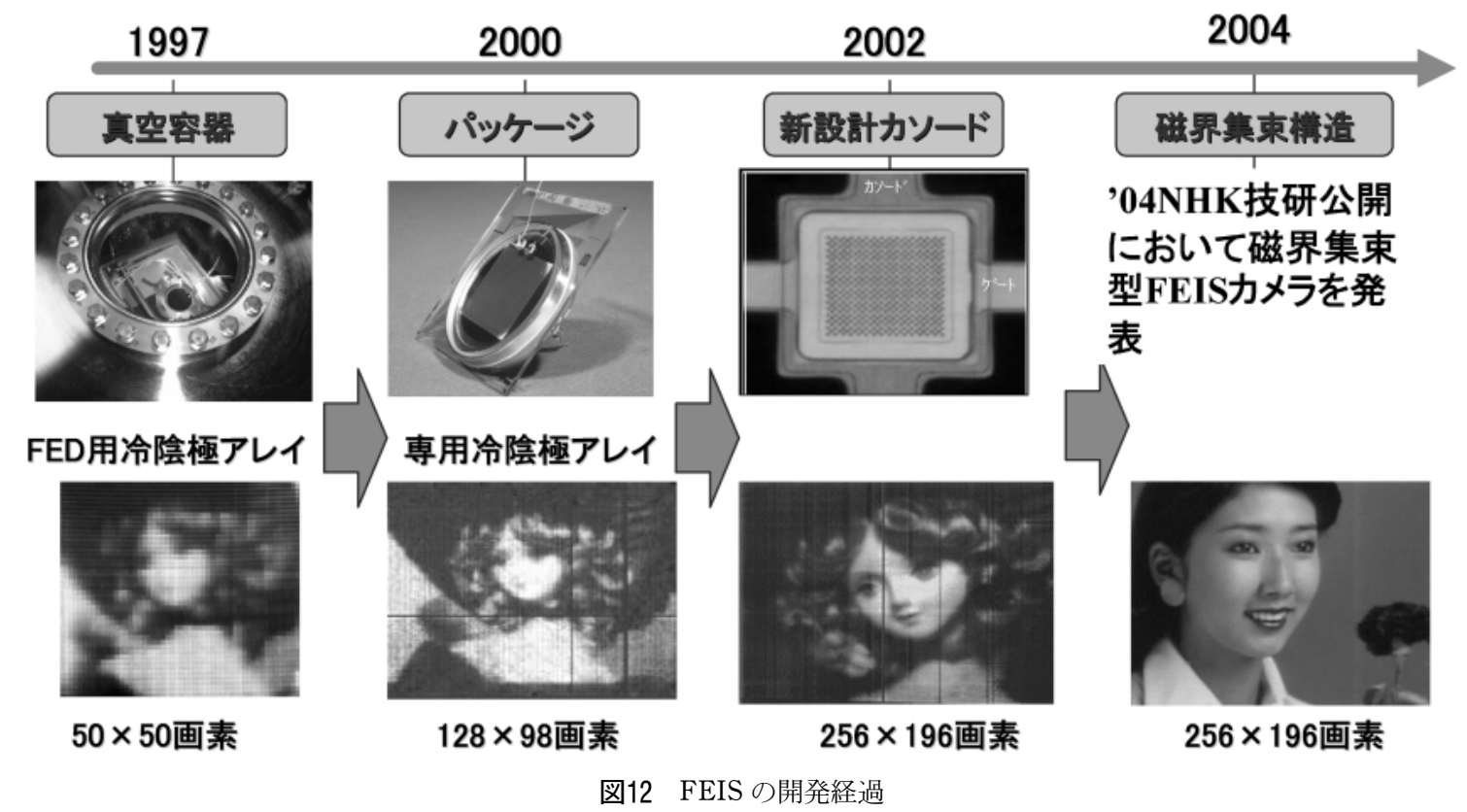

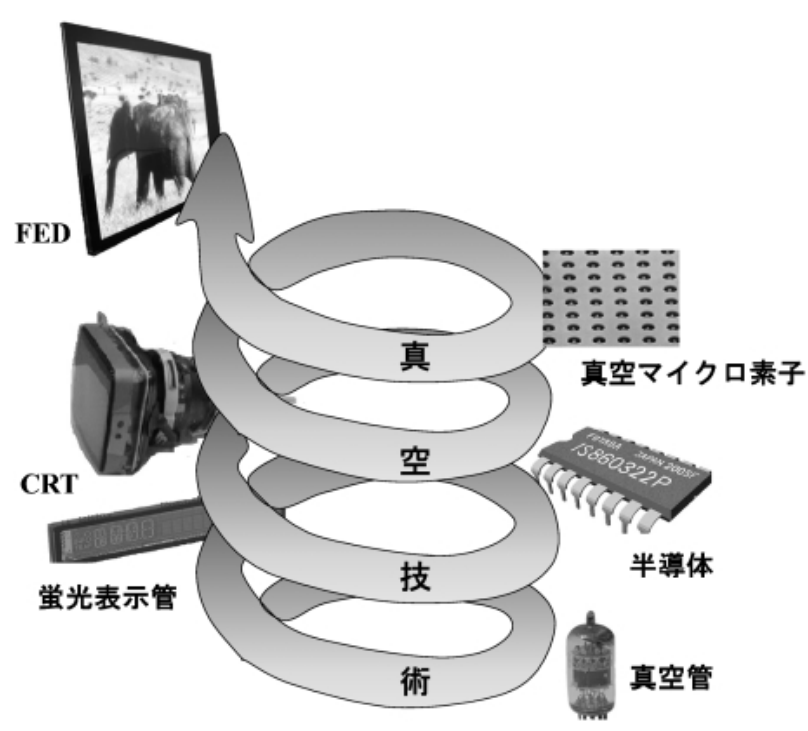

図13 真空技術の展開

の谷岡健吉放送デバイス部長, 江上典文主任研究員ほか関係 者との共同研究として実施された.

\section{[文献]}

1) C. A. Spindt, I. Brodie, L. Humphrey and E. R. Westerberg: J. Appl. Phys., Vol. 47, No. 12 (1976) pp. 5248-5263.
2) C. A. Spindt and L. N. Heynick: United States Patent, 3665241, May 23 (1972).

3) R. Meyer, A. Ghis, P. Rambaud and F. Muller: Tech. Digest of Japan Display '86 (1986) pp. 513-515.

4) M. Borel, JF. Boronat, R. Meyer and P. Rambaud: United States Patent, 4940916, Jul. 10 (1990).

5）難波, 山岸, 岡崎, 江上, 谷岡, 阿部, 高山, 田中, 伊藤 : 映像情報メディア学会誌 Vol. 54, No. 2 (2000) pp. 242-247.

6) S. Itoh, T. Watanabe, T. Yamaura and K. Yano: Tech. Digest of Asia Display '95, Hamamatsu, (1995) pp. 617-620.

7）伊藤 : 7. 電界放出ディスプレイ (FED),「フラットパネルデ ィスプレイ大辞典」工業調査会，（2001） 969.

8) S. Itoh and M. Tanaka: "Current Status of Field-Emission Displays" PROCEEDINGS OF THE IEEE, Vol. 90, No. 4, April, (2002) pp. 514-520.

9) M. Tanaka, Y. Obara, Y. Naito, H. Kobayashi, M. Toriumi, T. Niiyama, Y. Sato, S. Itoh and H. Kawasaki: Tech. Digest of SID '04, Seattle, (2004) pp. 832-835.

10) S. Itoh, T. Niiyama and M. Yokoyama: J. Vac. Sci. Technol. B 11(3), May/Jun, (1993) pp. 647-650.

11) S. Itoh, H. Toki, F. Kataoka, Y. Sato, K. Tamura and Y. Kagawa: IEICE TRANS ELECTRON., Vol. E82-C, No. 10, Oct, (1999) pp. 1808-1813.

12) S. Itoh, M. Tanaka and T. Tonegawa: J. Vac. Sci. Technol. B 22 (3), May/Jun, (2004) pp. 1362-1366.

13) S. Itoh, M. Tanaka, T. Tonegawa, Y. Obara, Y. Naito, T. Niiyama, H. Kobayashi, Y. Sato, M. Toriumi, Y. Takeya, M. Taniguchi, M. Namikawa, T. Yamaura and H. Kawasaki: Proceedings of the IDW'04, Niigata, (2004) pp. 1189-1192.

14) N. Egami, M. Nanba, Y. Takiguchi, K. Osada, T Watabe, S. Okazaki, Y. Obara, M. Tanaka and S. Itoh: Proceedings of the IVNC '04, Cambridge, Massachusetts, 4.1, (2004) pp. 228-229. 